\title{
The Arab Spring - Contemporary Revolutions in Historical Comparison
}

Mark Almond

Bilkent University

\section{Introduction}

In 1971 it was apparently "too early" for Zhou Enlai to give Henry Kissinger his assessment of the significance of the French Revolution. It is certainly too soon to sum up the importance of the events in the Arab world since January 2011. ${ }^{1}$ However, it seems reasonable to attempt an interim assessment of how the "Arab Spring" fits into the pattern of major revolutions and waves of upheaval since 1789. Such a review of similarities and contrasts between current events and past developments should provide some historical foundations for comparative analysis of the contemporary revolutionary wave in the Middle East.

The French Revolution of 1789 was often taken as the template for subsequent revolutions, both by revolutionaries and their opponents in the years following. ${ }^{2}$ But, of course, no successor - even in France - conformed to type. Although many participants in subsequent upheavals were influenced by memories and interpretations of French events after 1789, subsequent upheavals there diverged from the pattern set after 1789. The revolutions in France itself in 1830, 1848 and 1871 were full of echoes of 1789 , even conscious role-playing, ${ }^{3}$ but did not replicate the events or consequences of the period 1789-99. The revolutions in Russia in 1917 and China in 1949 are often viewed as the greatest political, social and economic upheavals since the "classic" French model, with similar global reverberations. However, the Europewide upheavals in 1848-49, along with aspects of another "Springtime of the Peoples", i.e., the collapse of Soviet-style Communism between 1989 and 1991, may offer more fruitful comparisons with current events in the Arab world since December $2010{ }^{4}$

The uprisings of 1848-49 and 1989-91 involved multi-national simultaneous outbreaks of revolution, and they seem more ambiguous than 1789,1917 or 1949 . Both $1848-49$ and the recent experience of the post-Communist revolutions suggest that the process of revolutionary

Mark Almond, Visiting Associate Professor, Department of International Relations, Bilkent University. E-mail: almond@ bilkent.edu.tr.

Supplementing the premier's apparent caution, Giovanni Arrighi reviews the unfulfilled predictions about China in his Adam Smith in Beijing. Lineages of the Twenty-First Century (Verso: London, 2007), 13-14. It is worth noting that mistranslation may have led Kissinger to think that Zhou was reflecting on 1789 rather than the more recent events in 1968, revealing the Chinese Communist to have been less concerned with the longue durée than the American conservative. See "Letters" in Times Literary Supplement (29 June 2012), 6.

2 For a review of the typology of revolutions on the bicentennial of the French revolution, see Matthew Soberg Shugart, "Patterns of Revolution" in Theory and Society 18 (1989), 249-71. On the eve of his fall in March, 1848, Metternich gloomily compared current events to the progress of the French Revolution year by year, thinking his Europe was at the 1792 stage: "Can 1793 fail to follow?" But events played out differently. See M.S. Anderson, The Ascendancy of Europe,, 1815-1914 (Longman: London, 1972), 97.

For Tocqueville's sense that the men of 1848 were sometimes playing roles premiered in 1789, see Hugh Brogan, Alexis de Tocqueville. A Biography (Profile: London, 2006), 427-28.

4 The most important study of the impact of revolutions on international relations since the later eighteenth century, David Armstrong, Revolution and World Order. The Revolutionary State in International Society (Oxford University Press: Oxford, 1993), neglects 1848-49 and was written, though not published, before 1989-91. 
change is not linear but filled with twists and turns. After 1848's sudden collapse of the old order, 1849 saw restorations, but they could not completely turn back the clock. Similarly, within a few years of 1989, old faces were back in high office across the ex-Soviet bloc but the planned economy was dead nonetheless. Progress and regression intertwined after 1848 and 1989 alike.

Assessing degrees of change and continuity is often highly subjective. Whether considering the specifics of one state's contemporary experience or a comparison across time and space, the distinction must be kept in mind between what outside observers and commentators make of possible comparisons and what locals think. (Of course, the particular commentators or locals and their interpretations are themselves sub-dividable into component sectors analysed by political, social and religious affiliations and so on.)

How far events in the past outside the Arab world impinge on and influence people in the contemporary Middle East is debatable, but as physicists have pointed out, it is not necessary to know about something for it to have an effect. Equally, "knowing" something which is not actually the case can influence one's behaviour or interpretations. ${ }^{5}$ Lessons which may seem obvious to one group are imperceptible to another, and so it was in the past, when transferring experiences across boundaries proved more difficult than merely hearing the news from "over there".

Of course, any discussion of the Arab Spring, even in comparison, must take account of the Middle East's own historical and cultural peculiarities even if lack of space precludes exploring them. It is also true that only with the passage of time will a full and multi-sourced account of these events be available to provide detailed resources for archive-based research on the specific mechanisms of political change - or the frustration of it - from Morocco to Bahrain. But, even in the absence of open archives, a preliminary attempt to put the Arab Spring into an international historical comparative perspective can still be useful as a means to help illuminate the unique and specific features of recent events. ${ }^{6}$ Any given Arab society's current crisis can be considered against possible models and alternative types of political revolution, if only to point out what is incomparable about contemporary events.

\section{From Immobility to Fluidity - the Pace of Change}

It is generally agreed upon by scholarly and media commentators alike that, after decades of apparently unshakeable rule, Arab regimes collapsed with remarkable speed. The fall of Zine el Abidine ben Ali, who had ruled Tunisia since 1987, and then that of Hosni Mubarak, who had been president of Egypt since Anwar Sadat's assassination in 1981, removed icons of Middle East politics. Not since the fall in rapid succession of Eastern Europe's Communist regimes in the latter half of 1989, when similarly immobile regimes imploded, had such a wave of revolution been seen. ${ }^{7}$ The violence in Libya, Yemen and then Syria added to

"Every school pupil knows..." things that are wrong. For instance, it was not the French Revolutionaries of the 1790s who asserted the sovereignty of the elected parliament - for them sovereignty still resided in the People - but, ironically, the ultrareactionary majority in the 1815 Chamber, which found themselves "more royalist than the king" when Louis XVIII chose to appoint ex-revolutionary and imperial ministers. The radical, Louis Blanc, noted, "It is they who proclaimed the dogma of the absolute sovereignty of the legislature". When the King dissolved the Chamber, "those who called themselves ultra-royalists were dismayed, and those who called themselves liberals applauded. It should have been the other way round". Quoted in Immanuel Wallerstein, The Modern World-System IV: Centrist Liberalism Triumphant, 1789-1914 (University of California Press: Berkeley, 2011 ), 48.

6 For instance, the study of sociology of crowds in 2011 is still in its infancy and highly impressionistic. It was not until the 1950s that George Rudé pioneered the use of police records to begin to classify who was on the streets of Paris in the key days of 1789. See George Rudé, The Crowd in the French Revolution (Oxford University Press: Oxford, 1959). 
the drama of events, but also complicated interpretation. If successful street protests in Tunisia, then Egypt seemed to mirror the "People Power" of 1989 in East-Central Europe, the internecine bloodshed in Libya, Syria and Yemen contradicted the neat comparison with the virtually bloodless collapse of Communism. ${ }^{8}$ However, even if we take into account the 600 casualties in Romania in December 1989 - the only violent revolution in Europe that year - it is clear that the death toll involved in removing Muammar Qaddafi from power after 41 years or sending Ali Abdullah Saleh into retirement after 30 years in power was far greater and the in-fighting far more bitter than in Bucharest two decades earlier.

The civil conflicts in Libya, Yemen and Syria naturally raise the argument that these are societies so different in their social structure, group loyalties and political dynamics from the non-Arabic communities experiencing revolution in the previous quarter century as to render comparative analysis fruitless and sterile. Critics of comparison will argue that the unique features of Arab culture make comparisons artificial when not misconstrued, but, without comparisons showing up the contrasts, how can what is actually unique be identified and separated from what is falsely assumed to be peculiar to a particular culture?

So far, the revolutions in the Arab world have been largely confined to republics, with Bahrain the only monarchy under serious pressure from street protests. The failure of street protests in Morocco, Jordan, Oman and eastern Saudi Arabia to "take off", the very modest political reforms in the first three monarchies and the successful rejection of concessions in Saudi Arabia suggest that hereditary monarchies enjoy either more legitimacy in general or a stronger cohort of institutional supporters than the would-be "republican-monarchs" in Egypt, Tunisia and Libya. (Only Syria had successfully transferred power from father to son in a "republic"). Nonetheless, despite the limits to change in the Arab world experienced so far, future historians will certainly record the instant judgement of the world media and external commentators that the changes in North Africa and Yemen as well as the civil conflict in Syria marked a turning point in regional if not global affairs. Even if contemporary perceptions turn out to be mistaken, they certainly are impacting current policymaking.

\section{Instant Assessments, Past and Present}

A brief review of the "instant" books listed on Amazon.com under the rubric "Arab Spring" reveals widely differing interpretations as well as the priorities of English-language publishers. Has the Arab Spring been hijacked by Islamists, and so is it a blow to US influence? Or is it steered by US agents? What are the social, generational or technological components of the upheaval? The titles seem to say it all: John R. Bradley, After the Arab Spring: How Islamists Hijacked the Arab Revolts, Hamid Dabashi, The Arab Spring: The End of Postcolonialism, The Guardian's Toby Manhire, The Arab Spring: Rebellion, Revolution and the New World Order, Bruce Feiler, Generation Freedom...9

Instant verdicts, even if proven wrong, tell us much about a revolution's immediate international impact. It is worth remembering how, for instance, in 1789 the news of the storming of the Bastille was taken at once to be earthshaking even if its consequences were often misjudged. News of the collapse of the absolute monarchy in France was greeted as

\footnotetext{
(2005) as well as Serbia (2000) are considered below.

8 It should also be remembered that more than 300 people died in Tunisia and more than 600 in Egypt, in addition to the as many as 30,000 casualties in Libya and more than 10,000 in Syria.

9 The reader may wish to determine the current "favourites" in the publishing stakes by entering "Arab Spring" in the Amazon.com search engine.
} 
a good thing across Europe, from London to St. Petersburg to Vienna: idealists saw it as a hopeful sign for human liberty, while realists thought turmoil in France would remove any chance of her causing international trouble for the foreseeable future and of her posing a challenge to their own state's interests. Both were wrong about the short-term consequences, given the onset of both the Terror and international war in 1792, but not necessarily foolish in their judgements. ${ }^{10}$

The speed with which assessments of the French Revolution were revised, dropped and forgotten is worth remembering by anyone assessing the Arab Spring today. Future conservative counter-revolutionary critics forgot their initial positive assessments. The British House of Lords was so taken by the storming of the Bastille and France's evident steps to imitate George III's constitutional monarchy that it immediately voted to make 14 July a public holiday in Britain. But the House of Commons did not reassemble from its summer break to consider the matter until after Louis XVI and his family had been forcibly dragged by the mob from Versailles to Paris, which was a constitutional development less obviously to be celebrated at Westminster, so Britons never got that midsummer Bank Holiday. ${ }^{11}$

Mistaken assumptions about the trajectory of revolutionary events were not confined to 1789. In 1917, the fall of the Tsar was welcomed by his allies. The British and French hoped that a "democratic" Russia would be a revitalized ally in the First World War, just as the French Republic had rallied people to its cause in the war against Berlin and Vienna after 1792. President Wilson used the argument that a democratic Russia was a natural ally of the United States to justify US entry into the war against Germany in April 1917, just as Lenin was returning home. In his War Message to Congress (2 April 1917), President Wilson referred to "the wonderful and heartening things that have been happening within the last few weeks in Russia". Wilson rejected any claims to legitimacy that Nicholas II had had, declaring, "The autocracy... was not in fact Russian in origin, character or purpose; and it has now been shaken off and the great, generous Russian people have been added... to the forces that are fighting for freedom in the world, for justice, and for peace". ${ }^{12}$

Wilson can be forgiven for thinking this. The leaders of the new Provisional Government took the same view. Searching for a precedent for the upheaval they were witnessing in Russia, they could only see what happened in France after 1789 as the appropriate model. Educated men like Prince Lvov, the new prime minister, or Kerensky, the energetic war minister, recalled that the French people had rallied to defend their new republic in 1917 against enemies who seemed familiar to them: the Prussians and Austrians had invaded France in 1792 to stifle the revolution, only to arouse a hornets' nest of popular resistance. Why should the events of 1792 in France then act as an inspiring precedent to Russians in their own time $?^{13}$ Everybody remembered Goethe's verdict as part of the defeated Prussian

10 For those taking a long-term view, it is possible to argue that despite the casualties of the Revolution, it laid the foundations of future freedoms by setting an example for idealists to follow - and realists might argue that after 25 years of Revolutionary and Napoleonic Wars France's international position was weakened. Many of those living in the short term might have found the consequences of the French Revolution less satisfactory compared with the widespread hopes in 1789 .

11 See Norman Hampson, Will and Circumstance (Duckworth: London, 1983), 3. Britain became the locus classicus of statesponsored counter-revolutionary activity, but only as the 1790 s progressed. By 1797 , for instance, the British secret service spent more money on subverting the elections in France than the ruling Directory there spent on managing them! See Donald Sutherland, France, 1789-1815: Revolution and Counter-Revolution (Fontana: London, 1986), 300-303.

12 Quoted in Cynthia Weber, Simulating Sovereignty. Intervention, the State and Symbolic Exchange (Cambridge University Press: Cambridge, 1995), 72.

13 This kind of reasoning brought into the open the culture gap between the educated leaders of the Provisional Government and the illiterate masses, which was then exploited by Lenin, similar to the way that secular opponents aware of 1989 or the colourcoded revolutions after 2000 have failed to grasp that these events are not lodged as models in the minds of most Arabs. 
army at Valmy: "Gentlemen, this is the beginning of a new epoch in history, and you can claim to have witnessed it". ${ }^{14}$

Nowadays anybody with a television, a computer terminal or the appropriate mobile phone app can be "present at the time". ${ }^{15}$ But as police officers are only too well aware, eyewitnesses are often limited in their perception of events because of their standpoint.

Academic historians have cast doubt on Goethe's eyewitness attribution of the French victory to revolutionary élan, emphasising the Republic's inheritance of Louis XVI's inflated bankruptcy-inducing military budget, not least his unparalleled artillery. But Goethe was no more wrong about the morale-boosting effects of revolution than the Allies and the Russian Provisional Government itself were in 1917 in reading into their contemporary situation the lessons of 1792. Ninety-five years ago the problem with the received wisdom was that the vast majority of ordinary Russians - unlike their Francophone elite - knew nothing about the parallels between the French Revolution and their own situation, nor did they want to carry on with the Tsar's foreign policy, only minus the autocrat, as provisional foreign minister Paul Miliukov promised the Allies. On the contrary, they wanted "peace, land and bread", though in fact Lenin would give them civil war and famine, so ordinary folk were no wiser about the future than their "betters". But what 1917 suggests is that outsiders or social groups cut off from ordinary people by status, education or sectarian background often see a pattern of events based on a reading of history, which is invisible or irrelevant to the bulk of people experiencing their own revolution.

\section{Foreign Inspirations or Foreign Interference?}

Today, outsider interpreters of the Arab Spring often bring their own knowledge of revolutionary precedents, like the largely bloodless collapse of Communism in 1989-91, or the original "People Power" revolution in the Philippines in 1986, to interpret current events in the Middle East. They rarely ask, however, what Arabs know or think about these "precedents". ${ }^{16}$ Suspicion of foreign models seems to have been widespread in Egypt, for instance, as evidenced by the few expressions of public sympathy when foreign NGO representatives and their local partners were arrested there.

Only Egyptians with an internet connection and an interest in accessing international NGO activities seem to have been aware of the precedents for anti-Mubarak web-based protest groups. When representatives of foreign NGOs came to Egypt who had experience in training activists and devising anti-regime propaganda exercises in countries like Milošević's Serbia before 5 October 2000 or Shevardnadze's Georgia in 2003, it was anti-Mubarak activists from the well-educated, secular "linked-in" generation who welcomed their support. ${ }^{17}$ But many other anti-Mubarak protestors were suspicious of American activists or US-backed NGOs from Serbia or Georgia. The subsequent crisis between Cairo and Washington in February, 2012 over the arrest warrants for foreign NGO activists operating in Egypt without formal

\footnotetext{
14 Quoted in Colin Jones, The Great Nation: France from Louis XV to Napoleon (Penguin: London, 2003$), 462$.

15 In another way of rendering Goethe's famous "ihr seid dabei gewesen" ("and you can claim to have been present"): what people see on their screens has immediacy but does not necessarily convey the complexity of events even when they seem to have been witnessed.

16 Given the large number of Filipino "guest workers" in the richer Arab states, it would make an interesting study to see what - if any - the impact from their experience of the Philippines' recurrent mass protests since 1986 that removed two presidents has had on their hosts. If anything, the fact that the Philippines remains a primary exporter of people rather than a political model is likely to dampen enthusiasm for imitating that model.

17 For the role of Serbian-trained graduates of the Qatar-funded "Academy of Change", see Jeffrey C. Alexander, Performative Revolution in Egypt. An Essay in Cultural Power (Bloomsbury: London, 2011), 35.
} 
authorization was acute, but it also revealed the limitations of support for such activities even among street protestors.

It was striking that although Egypt's Tahrir Square was the scene of recurrent demonstrations against the continuing influence of ministers and high-ranking officials of Mubarak's regime in the post-revolutionary government of Field Marshal Tantawi, there was no widespread protest against the detentions of the American and other foreign activists. Apart from his status as the long-serving Minister of Defence, until he gave the coup de grace to Mubarak Tantawi had also retained in office the chief accuser against the foreign activists under Mubarak-era regulations, Fayza Aboul Naga, a surviving minister from Mubarak's cabinet. Most Egyptian public outrage was, however, not directed at her but at the decision to release the foreigners on bail, giving them their opportunity to leave the country and effectively scuppering any Egyptian legal process.

\section{Turncoats, Weathercocks and Other Survivors}

The survival in high office of former dignitaries of the old regimes in Egypt, but even in countries with a violent upheaval like Libya, is not a peculiarity in the Arab Spring revolutions. If high-ranking officials of the old regime in France and Russia disappeared from their posts soon after 1789 or 1917, the recent revolutions in the ex-Soviet bloc have seen former Party secretaries and communist-era ministers return to high office, some through elections, some through street protests. In Libya, it was Qaddafi's longstanding comrades-in-arms over decades who led the uprising under the chairmanship of his Minister of Justice, Mustafa Abdul Jalil. The assumption of the de facto presidency of Egypt by Mubarak's previously loyal lieutenant, Mohammed Hussein Tantawi, was merely a bloodless example of the role of such insider regime changers. The well-connected US commentator on both the "Rose Revolution" in Georgia in 2003 and contemporary Arab affairs, David Ignatius, postulated that a key rule for contemporary revolutions was "Burrow from within. Like many reformers, [Georgia's] Saakashvili began as an insider with the regime he later toppled". ${ }^{18}$

Two and a half thousand years ago, Plato recognised that splits inside a regime were an essential precondition for successful revolution: "Is it not a simple fact that revolution in any form of government always starts from the outbreak of internal dissension in the ruling class? The constitution cannot be upset so long as that class is of one mind, however small it may be". ${ }^{19}$ Indecision and disagreement over how to handle street protests were fatal in the classic revolutions in France in 1789 and in Russia after 1917, but these revolutions by contrast with today's uprisings rapidly dispensed with the old regime ministers and high-ranking officers. Emigration, led by Louis XVI's brothers, started within days of the fall of the Bastille and the King's government was run by ministers with no past experience of high office. ${ }^{20}$ Similarly, in Russia, the Tsar's ministers and aides fell with him and were often arrested. By contrast, in Ukraine, Georgia and Kyrgyzstan, the new leaders were former ministers of the fallen regime $^{21}$ who had reinvented themselves as the crowds' heroes, criticising the corruption

18 See David Ignatius, "Six Rules for a Peaceful Democratic Revolution" in the Ottawa Citizen (13 July 2004).

19 Quoted from The Republic in Mark Almond, Revolution (DeAgostini: London, 1996), 30.

20 How different was the Restoration in 1815: who can forget Chateaubriand's evocation of the grotesque scene of Napoleon's former Minister of Police, Fouché, who had voted for Louis XVI's execution in 1793, and the Emperor's ex-foreign minister, the renegade bishop Talleyrand, kissing the restored Louis XVIII's hands on resuming office under the monarchy?

21 Georgian, Ukrainian and Kyrgyz insiders played ongoing roles, both when the Soviet regime fell in 1991 and then in the 
and incompetence of the old regime with the authority of insiders - though not necessarily changing too much of its modus operandi once re-ensconced.

However drastic the fate of the leaders of the old regimes after 1789 or 1917, focussing on what happened to the former elite after revolution or regime change as an index of how fundamental a revolution has been can be misleading. The executions of Louis XVI or Nicholas II certainly symbolised the far-reaching upheaval initiated by the revolutions in their countries. However, reflecting on the sea change in economic policies and property ownership in the former Soviet bloc after 1989 shows that even though - with the exception of Romania's Ceauşescu - no blood-letting took place, clearly a revolution in the socioeconomic order occurred. However, this socio-economic upheaval confirmed that many former members of the ruling nomenklatura became the political and economic elite of the new system. Many ministers of the old regime could rise to the top under the new democratic order, such as Aleksander Kwasniewski, elected president of post-Communist Poland as early as 1995. Multi-candidate elections since 1989 have transformed the way leaders were chosen but have not prevented many beneficiaries of the old order from providing much of the pool of candidates to run the new regime. Only time will ensure a generational change.

Even in the classic violent and apparently root-and-branch revolutions, a large part of the old order's personnel below the highly visible top rank remained in place. What distinguishes a revolution from a regime change is precisely that it affects more than personnel. Indeed, all manners of officials can remain in place but policy can be radically different. In Russia, for instance, it is true that the Provisional Government abolished the police, the gendarmerie and the Okhrana within days of Nicholas II's abdication, but as late as 1932 half of the Soviet civil servants employed then had worked for the old tsar - Lenin had admitted to the Comintern in 1922 that Communism could not function without them, "We pleaded, 'Please come back.'!" Trotsky remarked that a revolution changes everything - except the police. For instance, Nicholas II's expert codebreakers soon found they were indispensible to his murderers. ${ }^{22}$ The new state required skills acquired under the old one. And men accustomed to serving are willing to carry on under new masters. Ceva Grimaldi warned his tyrannical master, Ferdinand II, King "Bomba" of Naples, not to trust his bureaucrats to act as a pillar of his monarchy in 1848: "Public employees are generally happy to watch revolutions take place from the window, so long as someone goes on paying their wages". ${ }^{23}$

\section{6. "Lustration" - to purge or not to purge?}

People outside the old system, especially victims of informers and secret police arrests, often call for the "truth" about what went on before the revolution. After the collapse of Sovietstyle Communism between 1989 and 1991, similar calls for "lustration" were heard from East Berlin to Moscow as now echo in Tunis and Cairo. How can a revolution be complete if servants of the old regime remain in place, particularly if its secret servants, the small army of informers and undercover agents who paralysed opposition for decades, are not exposed and rendered impotent to influence politics in the future? Yet experience suggests that secret

22 For Lenin's Report to the Fourth Congress of Comintern, see Carollee Bengelsdorf, The Problem of Democracy in Cuba. Between Vision \& Reality (OUP: Oxford, 1994), 59. For the ex-Okhrana functionaries in the Cheka, see Richard Pipes, Russia under the Bolshevik Regime, 1919-1924 (Harvill/Harper Collins: London, 1994), 505, and Frederic S. Zuckerman, The Tsarist Secret Police and Russian Society, 1880-1917 (New York University Press: New York, 1996), 247.

23 Quoted in John A. Davis, Naples and Napoleon: Southern Italy and the European Revolutions, 1780-1860 (Oxford University Press: Oxford, 2006), 321. 
policemen and informers are the last people to threaten the new regime. On the contrary, they are natural collaborators with power, the last people to rock the new boat, provided their interests are not directly threatened. ${ }^{24}$ In any case, the compromising information which they have gathered remains potent under the new order, as the role of Kompromat in the internecine political warfare of Yeltsin's Russia suggested.

\section{Disappointed Expectations and Passive Revolutions}

Much more dangerous for a new post-revolutionary leadership are the disappointed expectations of their followers who helped them launch the upheaval. Engels pointed out 150 years ago that "[p]eople who boast that they have made a revolution always realise the next day that they did not know what they were doing, that the revolution they had made was quite different from the one they intended to make". ${ }^{25}$ Engels had in mind the illusions guiding the leaders of the 1848 revolutions across Europe.

The so-called Springtime of the Peoples seems a much better analogue with the Arab Spring than the classic revolutionary upheavals of 1789 and 1917. For all the international consequences of the French and Russian revolutions, they were - as common use of the "national" adjective suggests - primarily national events. Of course, Russia was a multinational state, but like it or not - and many "Russians" were dissatisfied - it was a single entity on the geo-political map in 1917.

There were of course foreign sympathisers with the French Revolution. Revolutionary émigrés flocked to Paris in the 1790s, much as fellow travellers went on pilgrimage to Moscow in the 1920s and 1930s - each sometimes regarded with suspicion as potential agents of the reactionary states that they had left. Certainly the symbols of the French Revolution became internationalised: tricolour flags - and the fasces that still decorate the French Republic's coat of arms (though they disappeared from Italy's after 1945) became republican emblems worldwide. The Marseillaise was a subversive song for at least another century. But when the revolutionary state tried to spread its model by force, the "armed missionaries" (to use Robespierre's phrase) encountered resistance more often than welcome. ${ }^{26}$

The French revolutionary model was too French for the Spanish, and stirred up nationalism in reaction to attempts to impose it. The same thing happened in Central Europe after 1917, because although identifying the events of 1917 as a "Russian" revolution overlooks the role of non-Russians in the fall of the Tsar and the coming to power of the Communists, most of the neighbours viewed it as a "Russian revolution". It is commonplace to categorise that what happened in the old Tsarist Empire was an illustration of a major factor in limiting the new regime's international appeal. Poles, for instance, have regarded Russia as the source of their country's loss of independence since the eighteenth century. As Catholics, they were in religious opposition to the Orthodox Christian Tsarist regime but were even less likely to look favourably on an atheistic movement coming from Moscow. Hungarians' bitter experience of Tsarist intervention to suppress their national cause in 1849 meant that the Soviet model had

24 See Mark Almond, Still Serving Secretly: Soviet Bloc Spies under New Masters (I.E.D.S.S.: London, 1992). To be fair, it should be admitted that scholars, too, often seem to show an innate ability to adapt to new regimes.

${ }_{25}$ Quoted in Mark Almond, Retreat to Moscow: Gorbachev and the East European Revolution (Institute for European Defence \& Strategic Studies: London, 1990), 23.

${ }_{26}$ Revolutions installed from abroad tended to be "passive revolutions", to use Neapolitan republican Vincenzo Cuoco's term), about the short-lived French-imposed republic that he served in 1799. See Davis, Naples and Napoleon, 3. The Communist regimes in Eastern Europe would not have come to power without the Red Army's presence there in 1945. 
limited appeal. Most Germans, too, were unlikely to regard Russia as a model for how their country should develop after its monarchy collapsed in 1918.

Of course, there were minorities of various kinds who saw hope in the Soviet experiment. But, for instance, if East European Jews had hoped that the Russian revolution would mark an end to religious discrimination, majorities in Poland, Hungary or Romania feared that outcome. Bigotry to the west was reinforced by the success of the Red Army inside Russia. Many of the fleeing Whites after 1920 brought anti-Semitic as well as anti-Communist ideas with them. In Germany, Adolf Hitler's pre-existing anti-Semitic and anti-revolutionary views were reinforced with stories of Soviet atrocities brought by émigrés who accused the Communist leadership of being Jews. Even German Social Democrats regarded the civil war and famine which beset the ex-Russian empire after 1917 as a warning of what they must avoid at all costs - even if it meant allying with the ex-Imperial army against more radical leftists like the Spartacists.

\section{1848-49 - the Forgotten Precedents}

The wave of revolution across Europe 70 years before the upheavals at the end of the First World War anticipated features of today's changes in the Middle East. In 1848, common grievances existed across Central and Southern Europe against entrenched regimes and poor social conditions and the disruptive effects of technological change as populations grew explosively despite these difficulties. Comparisons between the Arab world in 2011 with 1848 may also be more apposite because levels of literacy and availability of higher education are closer to mid-nineteenth century European standards than those in Central Europe in 1989. However, the availability of handheld communications technology is so widespread as to make the nineteenth century rumour mill seem decidedly primitive, at least in terms of the speed of communication across whole societies, but we should not forget the "electrifying" effect of telegraphic reports of the fall of the French King on the nascent protest movement in Berlin already squatting around the "Tents" in the Tiergarten in March 1848. ${ }^{27}$ The domino effect in 1848 was striking, much as the subversive effect of the news from Tunisia in January 2011 cut immediately across boundaries in the Middle East.

In 1848 , the revolutions were concentrated in capital cities. Of course, that is where the regimes' headquarters were too, but the mass of the population was still rural. This proved decisive. Religion rather than revolutionary ideology was the dominant intellectual force in the minds of peasants then. The first democratic elections on a universal (male) franchise in 1848 were held on Sundays, and often the clergy led voters from church services to public voting places where, to the disappointment of radical activists who had introduced "one man, one vote" a few months earlier, the majority voted for conservative candidates. This phenomenon was most obvious in France, where the "friends of the people", as the new provisional government saw themselves, not only proclaimed a republic but introduced genuine adult male democracy, only to see the swarms of newly enfranchised voters follow their Catholic priests from mass to the polling stations on the Sunday set down for voting and to elect a huge conservative majority. ${ }^{28}$

27 Long before Tahrir Square was occupied, or even Kiev's Maidan in 2003, tent camps were a revolutionary feature. See Hagen Schulze, The Course of German Nationalism, 7, and Christopher Clark, Iron Kingdom, 468, for Berlin in 1848.

28 Louis-Napoleon Bonaparte built his power base on that model and urged Prussia in 1861 to introduce democracy because "in this system the conservative rural population can vote down the liberals in the cities". Quoted in Anderson, The Ascendancy of Europe, 115 . 
Today, in both Tunisia and Egypt, secular liberals have been disappointed by how the mass of the population has voted when street protests in the capital have produced democracy. The victory of religious parties from Ennahda's plurality on a low turnout (52\%) in Tunisia to the absolute majority of candidates drawn from the Muslim Brotherhood and Salafist groups in Egypt's parliamentary elections, and of Muhammad Morsi in the presidential election (also on a low turnout) in June 2012, suggest that about half the population is not politically mobilised despite the dramatic events and also that among the politically active electorates religiouslyoriented candidates hold an edge over secularists, whether they are anti-regime as in Tunisia or ex-regime as in Egypt. These electoral majorities, along with the Islamist nature of many of the decrees issued by the Libyan transitional authorities, for instance, suggest that religion broadly understood to include a socio-economic agenda as well as narrower Sharia concepts is the key component of the new dispensation, at least so far as voters are concerned. This has put the Twitter generation of younger and maybe more literate, but also decidedly secular, activists in a dilemma: their protests played a key role in bringing about regime change, but a big crowd in Tahrir Square can turn out to be a modest minority in the ballot box. ${ }^{29}$

The nature of the newly elected majorities in Tunisia and Egypt, however, differs from the French model in 1848 in an important respect: even if secular radicals were downbeat about the victory of their religiously inspired opponents in the recent elections, their programmes and election promises were quite radical for the existing economic system, especially about ending the intertwining of business with the state apparatus. It remains to be seen whether the interwoven strands of Egypt's military-industrial complex will be unravelled. The decrees issued by the Supreme Council of the Armed Forces on the eve of the presidential poll there in June restricted the president's powers and retained to the generals wide authority, including over who would draft the country's new constitution. This echoed the decision in Prussia in 1849, after the army had suppressed street protests, to keep the forms of democratic elections but to drain them of potency by adapting the constitutional order to a hierarchical and authoritarian reality.

The 1848 Springtime of the Peoples is reasonably presented as the closest European historical precedent for the Arab Spring but the reactionary backlash in 1849 was too easily forgotten, despite forming part of the process. Keith Simpson, a former Sandhurst historian who is now the British foreign secretary's parliamentary aide, says: "The historical parallel for the Arab spring is not 1989, it is 1848-51. It is the European revolutions which saw in some cases regimes being overthrown and in other cases reactionary forces... able to hold on to power. I think it is the same with the Arab spring. It is mixed". ${ }^{30}$

\section{People Power or Personality-driven Protests?}

Revulsion concentrated on a single person makes for a powerful motivating force for a popular movement. Allegations of corruption at the top in 2011 corroded military loyalty in Tunisia and Egypt. Different in the Middle East from Central Europe in 1848 is how much the personification of popular discontent in 2011 was focused on one person as head of state

29 The crowds in Tahrir Square have had differing compositions over the months, but the Western media naturally tended to reflect the views and presence of English-speaking secular-minded demonstrators.

30 Quoted in Patrick Wintour and Nicholas Watt, "David Cameron's Libyan War" in The Guardian (2 October 2011): http:// www.guardian.co.uk/politics/2011/oct/02/david-cameron-libyan-war-analysis. 
and head of government. Although in France from the 1780s on, scurrilous rumours and cartoons of the King undermined royal authority, in Central Europe in 1848 it was ministers like Metternich, not the Habsburg emperor or the King of Prussia, who were the targets of popular anger. ${ }^{31}$ The mistake of Mubarak or ben Ali was not to have a front man to take the blame for the regime's failings and to be able to play the role of the benign monarch who "if he had only known" would have acted earlier to redress the people's grievances. ${ }^{32}$ Where monarchs retain legitimacy, they can sacrifice ministers and survive in power. But the clan nature of many of the Gulf states - like Qaddafi's "republic in one family" - undercuts the distance between monarch and people because ministerial and executive posts are often held by family members, who can be less complacently thrown to the wolves. The role of members of the al-Khalifa family in the day-to-day repression of Bahraini protestors meant that there was no clear firewall between the King and his agents. Richer rulers, like those in Riyadh, had cash reserves to buy off popular discontents - at least for the moment - unlike Bahrain, which has dwindling energy exports and whose role as a financial and tourist centre was hurt by the protests.

The lack of solidarity among authoritarian republican rulers in 2011 was striking. Monarchs in 1849 rallied together, but Mubarak stood paralysed as ben Ali fell. Algeria's generals and Bashar al-Assad abstained from the Arab League vote over taking military action in Libya. The Arab rulers split into monarchs led by the King of Saudi Arabia, and maybe bankrolled by the Emir of Qatar, against upstart republican despots whose families had not had the chance to entrench their clans or tribal members in key positions and locales over many decades, as had the more traditional monarchies.

Apart from Nicolae Ceauşescu's grooming of his son, Nicu, to be a future leader of Romania, nepotism was not a serious issue in the 1989 revolutions. ${ }^{33}$ Popular antagonism to the privileges and assumed corruption of the nomenklatura as a whole was certainly a big factor in the erosion of its authority across Eastern Europe, and then in the Soviet Union itself. But even East European Soviet-era elites were not family based in the way that the Arab regimes toppled in 2011 had become.

The revulsion at the inversion of once-republican or even radical regimes into increasingly clan or even family regimes was a key unique ingredient in the Arab Spring. The question of who would succeed decades-long presidents was becoming acute as old age marched towards its inevitable finale. Simmering succession crises preceded the outbreak of popular protest in Tunisia, Egypt, Libya and Yemen. So-called "republican monarchies" had been established. Long-term rulers like ben Ali, Mubarak, Qaddafi and Saleh were presumed to be grooming family members - usually sons - for the succession. This produced tensions with other key regime members. In Egypt, for instance, Mubarak's long-term defence minister, Field Marshal Tantawi, rejected the idea that son Gamal Mubarak, who had not done military service, had the qualifications for the presidency. ${ }^{34}$ Particularly when non-family members

\footnotetext{
31 See Anderson, The Ascendancy of Europe, 75-76.

32 Among republican despots, both Hitler and Stalin achieved this psychological hold over their people, many of whom attributed bad decisions and cruel acts to subordinates rather than the leader, just as medieval Englishmen preferred to blame their woes on "wicked counsellors" rather than their kings.

33 It is worth noting, however, that the two most in-bred Communist regimes, the Castros' Cuba and the Kim dynasty in North Korea, have proved that the Stalinist "socialism in one family" is a great survivor.

34 Although in both Tunisia and Egypt the army provided the coup de grace to the president, the scale of the military establishment in the two countries was strikingly different. Tunisia's army was small (even for a small country) with no more than
} 
in the power ministries defected from supporting the would-be president dynast, the regime tottered. Qaddafi managed to unite his quarrelling sons around him in the last six months of his regime but his veteran defence chief, Abdul Fatah Younis, deserted the leader whom he had supported since their coup in September 1969.

\section{The Syrian Exception}

It is not by chance that Bashar al-Assad's dynastic succession to the Syrian presidency occurred a decade before the Arab Spring; it gave him the opportunity to establish his own power base. At the same time, the distribution of key security posts to clan members or fellow Alawites cemented the regime's command-and-control so that defections or mutiny could neither paralyse it nor establish a rival centre of authority. Al-Assad's resilience under pressure recalls the monarchs of 1848, who made concessions to liberal demands and permitted parliamentary elections but kept a firm hold over the army. Prussian or Austrian officers could turn their largely peasant soldiers on rebellious urban centres, relying on rigid discipline but also the resentment of the countryside against the demonstrators in the cities seen as the privileged and often as children of landowners, rent collectors or tax officials. ${ }^{35}$ Parliamentary legitimacy had little power to set against the generals when they acted to suppress the newly elected assemblies in 1849.

\section{Democratic Peace Theory under Test}

The international aspects of the sudden victory of democracy in 1848 may be a warning about the future of the Middle East today. The idea of democratic peace is likely to be tested in the region as never before. For decades, Israel argued it was the only democracy there, and even when Lebanon was put forward as another one, the internal fissures of Lebanese society could explain away the state of war between Israel and its northern neighbour. However, since only autocrats like Mubarak and King Hussein of Jordan had the power to push through peace with Israel, the democratisation of Egypt with the Brothers of Hamas in the lead position will test the Camp David accords. Back in the springtime of Europe's peoples 160 years ago, it was widely expected that nationalism would be fulfilled by democratic states full of respect for each other's rights. A French liberal participant in the 1848 revolutions, Etienne Garnier-Pagès, wrote up his hopes for a Europe of free and independent nations: "There will be no more wars on questions of partition, domination, nationality and influence. No more weak and strong, oppressed and oppressors. Every country, free to enjoy its liberties and to live its own life, will hasten to join the life and liberty of all... The reign of peace, order and harmony will be founded". ${ }^{36}$ But as Edward Mansfield and Jack Snyder remind us, it was not only in 1848-49 that democrats fought to establish democracy, but also that new democracies are frequently belligerent and their peoples unwilling to countenance the idea that the rulers of another country are anything other than knaves and tyrants with whom engaging in diplomacy is wasted breath. ${ }^{37}$

40,000 service personnel. Maybe it could not have controlled countrywide protests even if it was willing to try. Egypt's armed forces were the tenth largest in the world, disposing of at least the equivalent of $10 \%$ of the country's GDP by comparison with Tunisia's meagre $1.4 \%$ on defence spending.

35 See Alan Sked, The Survival of the Habsburg Empire: Radetzsky, the Imperial Army and the Class War 1848 (Longman: London, 1979).

${ }_{36}$ From his Histoire de la revolution de 1848 in Anderson, The Ascendancy of Europe, 95.

37 See Edward Mansfield and Jack L. Snyder, Electing to Fight: Why Emerging Democracies Go to War (MIT Press: 
The rival Central European nationalisms in 1848 shattered revolutionary unity against the reactionary revival. Liberal Germans would not help Poles or Czechs against autocrats unless they bowed to German national interests. All lost as a result.

Unlike Central Europeans in 1848, Arabs today are united by a language and overwhelmingly by a religion. ${ }^{38}$ Identification with a particular state may be strong but pan-Arabic sympathies, or certainly the ability to follow via satellite TV and other media events from Maghreb to the Persian Gulf, are widespread. Of course, the Qur'an and Arabic literature are a unifying phenomenon, even if not readable by the tens of millions of illiterate Arabs. ${ }^{39}$ But whether the Arabs on the street protesting against their national governments want pan-Arabic or even pan-Islamic unity has yet to be demonstrated. It may be that the revolution in Tunisia suddenly lifted parochial cares from the shoulders of Arabs across the region, especially in Egypt, where the discontented seemed to think if revolution was possible in Tunisia, why not in Cairo? This domino effect could be seen in Eastern Europe in 1989 , too. But once the possibility of change was shown elsewhere, the actual revolutionary events were played out in a national context.

Will Arab revolutionaries today achieve what the revolutionaries of the old generation signally failed to establish - Arab unity? From Nasser to Qaddafi the anti-imperialist, proSoviet Arab revolutionaries of the post-colonial era dreamed, and certainly spoke, endlessly of their goal of pan-Arabism. But that dream failed because the leader of each Arab state presumed that his Egypt, or his Syria, even his Libya would be the heart of the new Arab commonwealth. Instead, they and their successors established the ossified regimes shaken in 2011.

Yet those regimes survived military debacles in 1967, for instance, without popular uprisings. Whereas defeat in war was the key spur to revolution in 1905 and 1917 Russia, Arab regimes had proved remarkably resilient in the face of military calamity. Saddam Hussein's regime survived his army's expulsion from Kuwait in 1991 and Nasser survived the loss of the Sinai peninsula in the Six-Day War. Even King Farouk took four years to fall after failing to stifle the birth of Israel in 1948. It was only after Mubarak's fall that the Camp David accords came into question in Egypt.

Apart from votes in the (toothless) Arab League, the post-revolutionary regimes have showed little enthusiasm for exporting their revolutions. Even the Libyan revolutionaries have confined their "internationalism" to sending a few volunteers and arms shipments to support the Syrian rebels. Despite the lack of warmth between Qaddafi and Hafiz al Assad, in the last days of the Colonel's regime, Syrian state media saw him as the victim of the same "international conspiracy" afflicting Bashar al-Assad's regime. But without the kind of NATO intervention that brought them to power in Tripoli, the Libyans' aid to the "Free Syrian Army" is gesture politics rather than a strategic input likely to impact in a decisive way on the conflict.

Wider conflict out of the revolutions in the Middle East seems unlikely. The cloud of war, more acutely over Iran's nuclear programme rather than Israel's existence, hung over the Middle East throughout the Arab Spring but not because of the revolutions. In fact, Iran's

38 Although, of course, sectarian rivalries between Sunni, Shiite and Alawite are significant sources of conflict in the crescent from Lebanon via Syria through Iraq to eastern Saudi Arabia and Bahrain.

39 The United Nations' Arab Human Development Report of 2002 is the locus classicus of data on the low levels of education and publishing in the Arab world, by contrast with neighbours like Turkey in all fields or even Iran in terms of female literacy and access to higher education. 
elderly clerics seemed to hope that the fall of Mubarak was the start of revolutionary process like their own in 1979. Iranian media like Press $T V$ continued to hail the Libyan uprising against Qaddafi even after NATO intervened and despite the leading hawks against Iran like Nicholas Sarkozy being in the vanguard. Given the failure of the Iranian revolutionary model to spread after the fall of the Shah in 1979 (despite the fears of Washington and Baghdad at the time), Teheran's belief that any religious component in the Arab revolutions must be similar to theirs back then was a triumph of parochial hope over international experience. ${ }^{40}$

External intervention as a counter-revolutionary force has been a recurrent feature of revolutions and the fear of it has often radicalised the interveners as alleged internal traitors; spies are rooted out as during the French Terror. It also weakens their international appeal; foreign sympathisers are often among the first to fall under suspicion.

With regard to external pressure for counter-revolution, it seems hardly likely that Saudi Arabia would have needed (putative) American prompting to see the preservation of a Sunni dynasty in Bahrain threatened by largely Shiite street protests as in its own immediate interest. Saudi Arabia also had the military power to act there, with the motive of warning off discontented Shiites in eastern Saudi Arabia from seeing Bahraini protests as a model.

\section{Western Intervention - "Leading from Behind"?"}

Pro-revolutionary intervention by the Western alliance in the Middle East may have followed the airpower model of NATO's Balkan interventions in 1995 and 1999; but unlike in Bosnia and Kosovo, or Afghanistan and Iraq, the Western powers have not taken control on the ground to install at least formal democratic structures and write the kind of inclusive constitutions guaranteeing the gender and minority rights that have been proclaimed there. The plethora of decrees issued by the interim Libyan authorities restoring polygamy, outlawing "glorification" of Qaddafi, etc. are a mixed bag of "Islamic" values and the de-Baathification instituted by the Americans in Iraq in 2003, but hardly fit any pattern of Western-imposed democracy.

The sudden decision to intervene in Libya in March 2011 took the world by surprise and certainly NATO's assets were not distributed as if a plan to act had been long prepared.

It has been commonplace for commentary on the collapse of Communism, or the fall of the Shah for that matter, to emphasise the failure of the US intelligence services to anticipate the upheaval. ${ }^{42}$ After 1989, the CIA was routinely reproached for failing to foresee the implosion of Soviet domination. Some suggest that despite Washington's calls for reform and democratisation in the Middle East, the US government failed to foresee the crisis of the regimes there, even though the region had been a vital centre of US diplomacy and power projection for decades.

The fall of US allies - ben Ali and Mubarak - in the first wave of the Arab Spring did not silence critics of US policy, not least in the Middle East. That a foreign hand must be in play in any regime change was a given for many people. Fred Halliday noted the prevalence of

\footnotetext{
40 Qaddafi's alleged role in the mysterious disappearance of Lebanon's Shiite Musa al Sadr 30 years' earlier was the ayatollahs' bone of contention with the author of The Green Book.

${ }^{41}$ For the much-disputed origins of this description of the US role in the NATO intervention in Libya, see Josh Rogin, "Who really said 'Obama was leading from behind'?" in Foreign Policy (27 October 2011): http://thecable.foreignpolicy.com/ posts/2011/10/27/who_really_said_obama_was_leading_from_behind.

42 See, for instance, Robert Jervis, Why Intelligence Fails: Lessons from the Iranian Revolution and the Iraq War (Cornell University Press: Ithaca, 2010).
} 
conspiracy theories in the Middle East as a reflection of the absence of democratic processes and the role of intrigue in autocratic regimes. But even a cataclysmic revolution like the fall of the Shah of Iran did not prevent a widespread belief among Iranians - shared in exile by Mohammed Reza Pahlavi - that the Americans must have pulled hidden strings to topple him for some nefarious stratagem of their own. ${ }^{43}$

But despite almost universal criticism of the role of the US in the Arab world and invectives against alleged "puppets" of Washington, at the outbreak of the Arab Spring the Americans' only real military bases were ironically in Iraq, from which they were withdrawing as the revolutionary wave started, and in Bahrain. Standing by the King of Bahrain has been US policy over the last 18 months, not least because the Fifth Fleet is based there (just across the Persian Gulf from Iran), but Washington has left it to a regional power to intervene to maintain the al-Khalifa dynasty.

There is some indication that the Tunisian army, for instance, with years of military cooperation with the US, was encouraged by American contacts not to crack down on the anti-regime protestors there and even to ease ben Ali into exile. ${ }^{44}$ Probably Washington decided that Mubarak was not salvageable and pressed the Egyptian Army not to intervene to protect the regime. But the officer corps had their own reasons for pre-empting any succession from Hosni to Gamal Mubarak. Shadowy British intelligence links built over decades with Qaddafi's spy chief, Mousa Kusa, probably prompted his defection, which was an important symptom of the regime's decay.

By contrast, the Syrian regime's ability to utilise military force in its crackdown may indicate that Western intelligence penetration is much weaker there as well as being a sign of the Syrian Baathist movement's own greater cohesion and resilience. Even Libya, after all, had undertaken military training links with Britain and America as well as with the nownotorious counter-Islamist intelligence cooperation, which gave western agents opportunities to penetrate Qaddafi's system, lacking in Syria.

The role of Turkey is much-debated inside and outside the country. Is the Justice and Development Party (AKP) model conquering the Arab election scene from Morocco via Tunisia to Egypt, or is the blowback of the Arab Spring making "Turkey turn Arab as never before...?"45 A return to the Ottoman past is sometimes glibly asserted in Western media that is not unsympathetic to seeing more Turkish influence in the Middle East, but fails to see how easily "neo-Ottomanism" can be used by, for instance, al-Assad's propaganda machine to arouse negative memories of the old imperial ruler of Syria. That AKP spokesmen do not mean neo-colonialism by neo-Ottomanism is clear - at least to many in Turkey. ${ }^{46}$

43 See Fred Halliday, Islam and the Myth of Confrontation: Religion and Politics in the Middle East new edition (I.B. Tauris: London, 2003), 64. It was not shared by the Shah's doomed ex-Prime Minister, Amir Abbas Hoveyda, who in his last minutes on earth in April 1979, rejected the Islamic Court's charge that he had been an agent of the US: "Your honour, if the Americans were really my masters, what would I be doing here now?" Quoted in Abbas Milani, Persian Sphinx: Amir Abbas Hoveyda and the Riddle of the Iranian Revolution (I.B. Tauris: London, 2000), 335.

44 US military aid to Tunisia was doubled after the revolution. See "U.S. general in Tunisia warns of stability threats" $A P$ (24 April 2012): http://www.washingtontimes.com/news/2012/apr/24/us-general-tunisia-warns-stability-threats.

45 See Elias Harfoush, "The Arab Turkey” in Al Arabiya (30 November 2011), quoted in Kılıç Buğra Kanat, "America's AsiaPacific Strategy and Turkish-American Partnership" in Insight Turkey 14:2 (Spring, 2012), 166.

46 Inside Turkey, Foreign Minister Davutoğlu's speech to parliament in late April 2012 attracted a lot of attention. His assertion that "[a] new Middle East is emerging,... We will continue to be the master, the leader and the servant of this new Middle East", was bitterly attacked by the opposition for advocating intervention, even "adventurism". See "Davutoğlu: Turkey Poised to Lead in Syria and New Middle East”, Middle East Voices (27 April 2012): http://www.middleeastvoices.com/2012/04/davutoglu-turkey-poised-tolead-in-syria-and-new-middle-east-79775/\#ixzzluME2BhNH. 
In addition to the opposition, some members of minorities worry that promoting democracy in Arab states is a cover for backing one group of co-religious against others. ${ }^{47}$ Whatever the truth of that, any intervention by Turkish forces, either to create humanitarian zones for refugees in border areas with Syria, or - more ambitious - to topple the Baathists from outside would risk Assad playing the ethnic card - Arabs, Armenians and Kurds versus Turks - and risk stirring up dissent among Turkey's different branches of Islam. However, in practice, the difficulties faced by US forces in Iraq after 2003, as much as any historical reflections on the failures of interventions in revolutionary situations, is probably the chief limiting factor not only for Turkey but its NATO allies. Libya was an easier option than Syria, even if a more prolonged and complex operation than anticipated in March 2011, and still far from internally settled. Syria's problems have the potential to spill over her boundaries, as threatened by Bashar al-Assad, though it could happen without his sponsorship. The outflow of weapons and ex-Qaddafi mercenaries from Libya has proved destabilising to regional neighbours like Mali more than to Syria.

Turkey's sudden abandonment of the "zero problems with neighbours" policy was controversial at home and abroad, but it plays the role of model democracy and market economy in many eyes, rather as Britain did for Europeans in 1848. The US remains the elephant in the room in any discussion of Middle Eastern affairs, both because of its influence as a superpower and because of its activities as a global political and economic model.

America's role as a revolutionary power has had its ups and downs since Lafayette's presentation of the keys of the Bastille to his old comrade-in-arms, first US president George Washington, in 1789. Rural revolts in 1789 and radical manifestations in the French countryside often coincided with places where French soldiers who had served alongside the American rebels against George III had returned after 1783. The impact of the American republic's establishment on French opinion should not be underestimated. Nor should Washington's ambassador Thomas Jefferson's admiration of the radical course taken by France after 1789 be forgotten, even if later revolutions, especially Communist ones, were seen as antithetical to the American model. ${ }^{48}$

Certainly, the promotion of democracy in the Middle East is one of the undoubted continuities in rhetoric and policy from George W. Bush to Barack Obama, ${ }^{49}$ but how far the Arab revolutions were sponsored and influenced by American actions or agents is far from clear. The grandson of the founder of the Egyptian Muslim Brotherhood, Tariq Ramadan, ties himself into knots trying to assess and rebut claims that Washington was behind its dramatic political rise after February 2011..$^{50}$

Of course, Americans have long wanted the rest of the world to adopt, or at least adapt to, its model of market democracy. Becoming "like them" was supposed to guarantee peace and prosperity. For many people in Eastern Europe and the USSR in the late 1980s, adopting the Western model, "returning to Europe" and joining the EC quickly was seen as the high

47 See Sami Kohen of Milliyet, quoted in Dan Bilefsky, "Despite Bold Talk on Syria, Turkey Sees Limits of Its Power" in New York Times (16 March 2012): http://www.nytimes.com/2012/03/17/world/europe/despite-bold-talk-on-syria-turkey-sees-limits-ofits-power.html

48 R.R. Palmer, in The Age of Democratic Revolution. A Political History, 1760-1800 (Princeton University Press: Princeton, 1959) emphasised the trans-Atlantic political crosscurrents.

49 Compare President Bush's speech on the twentieth anniversary of the National Endowment for Democracy on 6 November 2003 (http://www.ned.org/george-w-bush/remarks-by-president-george-w-bush-at-the-20th-anniversary) and President Obama's speech in Cairo on 3 June 2009 (http://www.nytimes.com/2009/06/04/us/politics/04obama.text.html?pagewanted=all).

${ }_{50}$ See Tariq Ramadan, The Arab Awakening. Islam and the New Middle East (Allen Lane: London, 2012). 
road to freedom and prosperity - though the path has turned out more twisted and bumpy than anticipated.

Whether Arabs are as enthusiastic about joining the Western club remains to be seen. In the Arab world, the division between oil-rich emirates and poor-but-populous republics makes any kind of integrated "Arab Union" impossible without fundamental changes in Saudi Arabia and the other monarchies. But even change there might not produce more economic sharing. After all, the rich democracies of Western Europe were much less generous to their poor Eastern cousins after the collapse of Soviet domination than the United States was to the Western Europeans through the Marshall Plan at the height of Soviet power.

Although America's ally, Saudi Arabia's role in the Arab revolutions has been Janusfaced: the Saudis may be funding, even helping to arm, the Syrian rebels, but the Saudi Arabian army has been in the vanguard of counter-revolution in Bahrain. Without Riyadh's military intervention, the al-Khalifa regime might have collapsed in the face of protests in Manama. To use NATO terminology, Saudi Arabia multitasks when it plays the role of Nicholas I's Russia of 1849 and Lenin's of 1919 simultaneously. It is a bold balancing act.

Russia today is certainly not the Russia of 1849 , but since the colour revolutions in Georgia, Ukraine and Kyrgyzstan, probably sponsored by, and certainly applauded in, Washington, Russia's Vladimir Putin has viewed regime change as a threat to his system. China, too, is concerned about any wave of revolution.

The twentieth century's two key centres of revolution have become the twenty-first's stumbling blocks to revolution, at least in so far as they use their permanent seats on the UN Security Council to block intervention in favour of regime change. Russia's abstention on Libya in March 2011 looks set to be as unique as Stalin's boycott of the Security Council in the run-up to the Korean War in June 1950: it was a geo-political mistake not to be repeated.

The Americans urge the Russians to get on "the right side of history", but whether the Arab revolutionaries want the kind of democracy and other reforms acceptable to Washington or are bent on a theocratic Muslim Brotherhood-run regime, there is unlikely to be much place for Moscow's influence in the near future in post-revolutionary states. Partly because of Putin's repression of the Chechen rebels, neither Arab secular liberals nor Muslim activists have any sympathy with the current Russian regime. Therefore, Moscow hopes to hold on to what is left of the influence inherited from the Soviet Union: Assad's Syria and possible links with Algeria. Those pieces are all that remain of Russia's revolutionary heritage in the Middle East, from the golden days of its alliances with Nasser at the heart of the region.

\section{Interim Conclusions}

The unpredictability of revolutionary outcomes in the past suggests caution in making predictions of more recent ones; however, some sub-patterns are emerging across the Arab world.

In Tunisia, a parliamentary regime seems to have been established. In Egypt, the electoral process continues, despite occasional bloody clashes in the streets and rulings by the Constitutional Court and SCAF invalidating parts of the process. The existence of the state seems secure in those two cases, even if their internal forms are still to be determined. But despite regime change, quasi-civil war reigns in large parts of Yemen and Libya, where de facto self-government has been established in Benghazi and Zintan. The integrity of the state as well as its constitution is still contested in both places. If the Syrian regime suddenly 
implodes, a quick consensus on a future political order is hard to imagine. Territorial division would also be an issue there, which would affect Syria's neighbours.

Instability has grown dramatically in the Sahel since the fall of Qaddafi. The Colonel's generosity with Libya's oil revenue to neighbouring regimes (as well as sub-Saharan Africa) means that his fall has contributed to the economic destabilisation of regimes to the south and west, which are also endangered by the repatriation of workers and mercenaries from Libya since the revolution. However, the upheaval in Mali, for instance, seems to be setting the country on a contrary course to the democratisation at least hinted at by the Arab Spring. Tuareg rebels and Islamist fighters in the north and a military coup in the capital, Bamako, have set Mali on a course of disintegration rather than revolution. ${ }^{51}$

Even in the Gulf, stirrings of unrest and rivalry between regimes that might seem to share the same forms make predicting continuing stability far from certain.

Regional powers, like Turkey and Israel, not affected by revolutionary challenges view the changes differently. What for Ankara is an opportunity for a dramatic growth in influence and cooperation across the vast southern region is a potential threat to Israel, since its democratic status was part of its unique legitimacy in the international public relations competition with the Palestinians and their Arab backers. Iran may face internal challenges as it approaches middle age, but the quiet revolution in Iraq is to its advantage, even if no new Shiite friends have come to the top elsewhere in the region.

For the US and Europe there is the question of whether their foreign policy interests will be best served by Arab democratic regimes more responsive to the man in the street than authoritarian rulers. Washington and Brussels have wanted democracy, but perhaps they should have been careful in what they wished for.

Foreign policy issues have played a remarkably small role in the public rhetoric of the Arab uprisings. Even in Egypt, the chief source of tension with Israel has been the terms of their gas deal rather than the Palestinian question. Allegations of corruption to the benefit of Mubarak's family by selling natural gas to Israel at a lower-than-market rate in return for kickbacks were corrosive before 11 February 2011, and have become explosive since. Sporadic attacks on the pipeline have repeatedly cut gas supplies to Israel. They also reflect the growing disorder in the formerly tightly controlled Sinai.

Ordinary Arabs in very large numbers have wanted freedom, democracy and prosperity, but now face the age-old problem of revolutionaries: toppling the old rulers does not immediately remove the legacy of bad policies or alter basic facts of economic life. Disappointment is a natural part of revolutionary enthusiasm. In his study of what went wrong in France after 1789, Norman Hampson emphasised the sincerity of the people in wanting to change everything for the better. The principle of hope was a key motor of willingness to take risks for change, then as now, but the French revolution was a tragedy precisely because the great hopes of a better world that it aroused, that in fact spurred it, were frustrated - at least in the short term. But Hampson concluded that the ambitious rhetoric of human rights and civic representation in 1789 should be taken seriously, even if the political actions disappointed: "From the bleak and cynical viewpoint of our own times, it may be difficult to take these professions [of faith] at face value, but those who dismiss them as insincere will never

${ }^{51}$ For a focus on the implications of counter-terrorism on the growing disorder around Libya, see the Heritage Foundation's "Crisis in the Sahel: Bitter Fruit of the "Arab Spring”" (9 May 2012): http://www.heritage.org/events/2012/05/crisis-in-the-sahel. 
begin to understand the French Revolution". ${ }^{52}$ A similar point should be made about the Arab Spring, as post-revolutionary difficulties and divisions appear, especially in Egypt and Libya, and despite the continuing anti-revolutionary campaigns in Syria and Bahrain. These unexpected, unpredicted revolutions will hardly follow a smooth course set out in social science textbooks.

The disappointed English romantic revolutionary William Morris reflected in his Dream of John Ball on the mysterious ways in which history developed and produced unanticipated results from the point of view of rebel and reactionary alike. What Morris concluded from his poetic review of the failure of the Peasants' Revolt in 1381, and other failed revolutions in English history or even successes like the decapitation of the monarch in 1649, was that what happened in the long-term was not what anyone had expected: "I pondered all these things, and how men fight and lose the battle, and the thing that they fought for comes in spite of their defeat, and when it comes turns out not to be what they meant, and other men have to fight for what they meant under another name". ${ }^{53}$ After all, for good or ill, that is what happened decades after 1848-49 to the nationalist dreams that had motivated many democrats. Perhaps those contending in the Arab world today will conclude in time that their confused struggles produced a similar result - over the long term, which not everybody lives to see or to enjoy. 